\title{
MONITORING CONSUMER NEEDS IN THE FUNCTION OF MAKING EFFECTIVE STRATEGIC DECISIONS GIVEN ON THE EXAMPLE OF THE "SEDMICA PLUS" LLC TRAVEL AGENCY
}

\author{
Gordana Gavric, Assistant Professor ${ }^{1}$ \\ Jelena Milanovic, "Sedmica plus” Travel Agency²
}

DOI: https://doi.org/10.31410/tmt.2018.311

\begin{abstract}
Unless a company is state-owned, the relationship an organization nurtures towards its consumers is nowadays a significant factor of success and competitiveness. The aim of this paper is to point out to the significance of monitoring consumer needs in modern business conditions and to, in the empirical section of the paper through research results, give specific suggestions to the management of the "Sedmica plus" Travel Agency from Negotin concerning the improvement of their business and in accordance with the needs and wishes of their travellers.
\end{abstract}

Keywords: tourism, consumer needs, strategic management

\section{INTRODUCTION}

$\mathrm{T}$

The interest for exploring the monitoring of consumer needs lies in the fact that in today's business conditions the monitoring of consumer needs is considered exceptionally important when it comes to making good-quality strategic decisions and achieving longterm efficacy of any organization.

Modern business conditions are characterized by quick changes, uncertainty, insecurity, reduced life cycle of products and services, more sophisticated consumer requests, etc. Organizations are faced with serious challenges and one of the greatest is how to attract and retain consumers and/or clients.

If a company wishes to have a successful business, it needs to position itself on the market as a responsible and innovative company that keeps up with contemporary trends and in a successful way meets even the most sophisticated consumer and client needs. The ability to adapt to changes, i.e. organization's adaptability, has become one of the most desirable characteristics of any modern organization that thinks about its future in a responsible manner. In other words, constant monitoring of market changes, quick reactions to current trends and anticipation of future happenings are characteristics of successful and modern organizations. The ultimate goal is to retain the existing and attract new consumers or clients in order to improve the final successfulness of a company.

Hence, a modern organization's successful business is tightly connected with the culture of the consumer relationship which is also said to be the highest domain of corporation's public relations. Consumers are unpredictable and can easily walk away attracted by an attractive promo activity. The basic task of customer relationship is to make them loyal to the company, i.e. a product or service. In this regard, the question is if and to what extent today's managers keep track of their customers' needs and if they consider them when making decisions regarding the organization's business future.

\footnotetext{
$1 \quad$ Faculty of Business Economics and Entrepreneurship, Mitropolita Petra 8, Belgrade, Serbia

2 "Sedmica plus" Travel Agency, Hajduk Veljkova 42, Negotin, Serbia
} 
The basic motto of the "Sedmica plus" Travel Agency from Negotin from the very beginning of their business has been that earnings and profit should not be on the first place, but rather satisfied travellers. In that sense, the top people in the agency chose the following sentence to be their slogan - "No. 7, your lucky number!" In that way, they wanted to tell their travellers that they want to make each of their journeys feel like they have just won the lottery and to return from their holidays relaxed, in good spirits, happy and with the best of impressions. This paper offers research results concerning current needs of the clients of the "Sedmica plus" Travel Agency from Negotin and their desires from which certain recommendations for the improvement of the business in question will be drawn.

\section{MODERN CONSUMER NEEDS}

A consumer is a person that owns money and the will to buy products and services that he then uses to satisfy personal and family needs. Needs that are to be met go from hunger and thirst, love, status, to development or even spiritual fulfilment. Likewise, a consumer can be an economic entity, i.e. a certain institution that buys products and services and uses them to perform his/its basic activities.

Competition, which represents a characteristic of the modern market, has put a consumer in a different position comparing to the one he was once in. A consumer is today seen as a business partner of a company and all of them want his loyalty. Without consumers there can be no business organizations. In that sense, a responsible organization takes care of its consumer needs and strives to find the best possible ways of meeting those needs. The purpose and ultimate goal of every company is to have satisfied buyers. Only those organizations that are aware of this fact can count on success. To support this statement, we will present a few examples further on in the text.

Amazon is a company whose work is characterised by a constant desire to achieve the greatest possible benefit for the buyer by continually introducing innovations. Amazon has become one of the leading e-commerce platforms in the world (Amazon.com) by enabling book lovers around the world to search for and buy books by choosing from more than a million book titles and all that from the comfort of their homes. Dell Company has become the largest world computer seller thanks to the fact it has "constantly made new concepts and outperformed its competitors" [1] by offering the best products to its consumers.

The importance of customer-focused strategy has enabled many companies to come to life all over again after having gone through crises. For example, after a serious crisis in 1993 the IBM Company came back to the global market scene thanks to the attitude of the then chief executive officer Louis Gerstner who emphasized that the key to going back to the top was the customer-focused strategy, the only strategy which could make the company successful again [2].

A globally-known example that serves as a lesson to all organizations is the case of Nokia. Due to its arrogant behaviour and lack of adjustment to market needs, i.e. its clients, the once strongest brand in the field of mobile telephony had forever left the throne.

In the vast field of tourism, the basic precondition for a successful business is to understand the need for setting aside the conventional and transitioning to the electronic distribution of travel services. By implementing the e-business system, a small travel agency from Italy called Run21 managed to efficiently perform many time-consuming tasks - its employees could quickly send 
feedback to their clients, they could sell and offer solutions to other travel agencies and smaller tour operators. And, by implementing last minute bookings, they conquered a large portion of the market. By innovating their business in accordance with their clients' needs, they became even more successful with only 5 employees doing all the work [3].

Organizations must never neglect the fact that consumers are becoming more and more educated every day and are attaining massive amounts of information before deciding to buy a product or use a service, and they almost always consider possible alternatives. Research shows that:

- Annually, $40 \%$ of satisfied clients still go to other retailers and

- $98 \%$ of unsatisfied buyers never complain, they simply go to other places [4].

The fact is that today's consumers have a large choice of products in offer, hence it is very important to get closer to them in a way that would be different from what the competition has to offer in order to attract and retain their attention and keep them loyal to the company. Retaining only $5 \%$ of loyal customers can double the profit, while the expenses of attracting new buyers can be 5 times larger than the expenses of retaining the existing consumers [4], which is very important for organizations from the aspect of economic justification of making decisions that will be in accordance with monitoring the needs of the existing consumers.

Modern business marketing strategies rely on increasingly complex analysis techniques and needs assessment, be that for the sake of getting to know them and use them, or for the sake of challenging new needs, and always with the aim of increasing sales and profit [5].

Every organization wants to make the biggest possible profit and the only way to achieve that is to give the consumer an offer, i.e. a product or a service, which would meet his needs and desires. Customer analysis deals with who buys, what, why, how they make decisions, when, where and how often they buy products and services.

\subsection{Characteristics of tourist offer}

Tourist needs belong to a separate group of needs named "secondary" or "additional". Only when there is enough free time, a certain level of the quality of life and financial resources, i.e. money, can the motivation to travel be born [6]. Tourist offer is in itself complex and of versatile content and structure and is seen as the need for transport, accommodation, food, entertainment, recreation and other similar contents. This means that when having one individual tourist and his needs, the agency needs to provide a series of different services that represent one complex tourist offer.

The global trend of the world tourist market, within the overall globalization, is focused on tourists' consumer preferences that keep on changing due to quick economic, technological, cultural, political and other changes.

Today, tourists pay a lot more attention and significance to the quality and values when making their purchasing decisions. The quality in tourism implies that the tourist offer needs to fulfil all the crucial conditions such as: safety, publicly and otherwise available information about a specific offer, offer originality, hygiene, etc.

Empirical research shows that tourist needs are often met in a way that cumulates various pleasures, starting from physiological and rational ones, ending with very irrational ones [7]. The estimates are that in the future period the highest growth rates of tourist traffic will happen due to 
the following 11 tourist products: sun and sea - intercontinental journeys, combined journeys; sports tourism - winter and summer, adventure tourism; tourism in nature; cultural tourism, urban tourism; rural tourism; cruises; theme parks; meetings and conferences; health tourism [8].

Often happens that several agencies offer a completely identical package deal, but in addition to the price which can often have an important role when making a decision, more important is the reputation the agency has in the eyes of the consumers, based on previous personal or someone else's experience. Every travel agency strives to build its reputation on the satisfaction of its clients, hence the quality of service is of the utmost importance. One of the primary goals of business companies in tourism is to create loyalty to the brand which would result in partnership, repeated purchases and positive recommendations. According to Petrovic and Dzeletovic [9] the three factors leading to customer/tourist loyalty are:

- Customer satisfaction growth achieved through quality growth;

- Customers trust in the company and its products and services;

- Establishing cost penalties for the transition of customers to a competitive bidder.

In conditions of a very unstable tourist demand, only the customer-focused approach, which is the essence of the contemporary marketing concept, can enable successful business and market survival [8]. Loyal buyers bring continuous profit, hence the cooperation in all fields of tourist offer can be established with loyal buyers.

\section{STRATEGIC MANAGEMENT IN THE FUNCTION OF COMPETITIVENESS}

Competition on the local tourist market creates a different growth and traffic of tourists in every travel destination. In order to increase profit, it is necessary to have a strategic plan with the aim of achieving market advantage [10]. In every planning model, it is important to make connections between the strategy and operative processes since many research endeavors show that it is much easier formulating than implementing new strategies, and less than $10 \%$ of successfully formulated strategies are successfully implemented [11]. For a strategic planning to be successful, it also needs to include the assessment of customer needs. In that sense, adaptability of organizations based on assessing customer needs should become the primary task of modern managers. Adaptability is not a characteristic of the new age, only the need for it is more intense now than it was ever before. Simply put, conditions in which organizations do business demand an answer without which the result is often organizational death [12]. In the years to come, when according to Hamel and Breen "the competitive anarchy is on the rise" [13], the level of organizational adaptability, as well as people and societies as a whole, shall be put to the serious test.

Research on the adaptability of companies in the Republic of Serbia [14] has shown that the average adaptability grade is 3.50 which is the value slightly higher than grade 3 described as "neither agree nor disagree" and lower than grade 4 described as "mostly agree". This shows that companies in Serbia should work on the adaptability in all business areas in order to respond to changes in a better way. Likewise, the same research has pointed out to the difference in the level of adaptability in local and foreign companies wherein research results have shown that new and enhanced work methods are adopted to a higher degree in foreign companies, that they keep more thorough track of customer needs and desires, hence they take them into account when making decisions. Also, foreign companies are more in favor of a direct contact with their buyers. Innovativeness, i.e. the ability of an organization to constantly create and adopt new work methods, has been identified as a very important adaptability factor. Hence, we can conclude that companies 
in the Republic of Serbia should work on the enhancement of their adaptability and that local companies have to look up to foreign ones doing business on our market. What is good here is that, according to the same research, the tourism sector is more adaptable in comparison to other economic branches and there is a lot room for progress in the continual education of participants involved in tourism activities, as well as in including employees in the planning process. The results have also shown that tourism, more than any other branch, encourages direct contact with tourists (clients). However, there is a problem that has been noticed in almost every company in the Republic of Serbia, and that is the problem of motivation of the ones employed in tourism, as well as the involvement of employees in the planning process and education of employees [15].

There are many definitions of the term competitive advantage and based on them it can be concluded that it is a multi-dimensional phenomenon, i.e. a combination of multiple performances by which a company expresses its superiority in comparison to its competition whose line of work is congruent or the same and by which it achieves a successful business, i.e. achieves profitability higher than average. If an organization or an institution wishes to be competitive, it needs to have adequate and powerful resources. Generally speaking, most authors agree on the four main pillars of competitiveness: quality, innovations, customer relationship and the economics of scale [16]. This is why it can be said that an organization that in the $21^{\text {st }}$ century brags about its consistency in doing business, commonality of its products or status quo, is more in the period of stagnation than that it is successful and stable [17].

When making a decision about buying a tourist product, a potential tourist goes through a series of different decision-making stages, and the information on where a certain (specific) product is in comparison to a competitor's product gives a clear picture to consumers and users [18]. The existing competition is not the only one that matters, but also the one that is yet to come, and on the tourist market, very common are surprises exactly in the field of innovations and implementation either of new destinations or new products, i.e. services. It is important to mention that innovation for the sake of innovation is not enough. Namely, the main cause of an unsuccessful innovation is the creation of something nobody needs, the improvement of something that is already of good quality or the enhancement of possibilities of products or services that have no use. It is necessary to observe customer needs and look at the offer from their point of view and in that way detect problems in order to solve them. A solution to such problems is something a consumer will gladly pay for, and innovations based on such a principle will surely find their way to reach the market. It can be concluded that, if a company wishes to make good-quality decisions and do successful business in the aim of achieving competitive advantage, the management needs to continually monitor market happenings and customer needs.

\section{METHODOLOGICAL AND HYPOTHETICAL RESEARCH FRAMEWORK}

The research was carried out with the use of a survey. The survey is of a combined type and was personally distributed to interviewees. IBM SPSS 21 program package was used for the processing and interpretation of data.

The research was carried out on a random sample consisting of the current clients of the "Sedmica plus" Travel Agency from Negotin. A total of 111 interviewees took part in this research. The research was carried out during the year of 2018. 
The primary research hypotheses are:

1. Travellers of the "Sedmica plus" Travel Agency from Negotin are satisfied with the current offer and they do not want to expand it.

2. Finances are an important factor when choosing a destination.

The empirical research was carried out in four stages:

1. data collection;

2. sorting and grouping of data;

3. statistical analysis data processing (descriptive analysis, factor analysis and predictive model) and

4. interpretation of the obtained data.

\subsection{The sample structure is as follows:}

According to the obtained data, $36 \%$ of male and $64 \%$ of female interviewees took part in this research.

The highest percent of interviewees (35.1\%) are between 40 and 55 years of age. A slightly lower number of interviewees, $26.1 \%$, are between 30 and 40 years of age. There are $18 \%$ of interviewees aged 20 to $30,9.9 \%$ of the ones aged 55 to $65,7.2 \%$ of interviewees are over 65 years of age and the lowest percent of interviewees (3.6\%) aged 15 to 19 .

The highest percent of interviewees (64\%) are employed, while the lowest percent $(1.8 \%)$ are high-school students. There were $12.6 \%$ retired interviewees, $6.3 \%$ college students, $5.4 \%$ unemployed interviewees, while $9.9 \%$ interviewees did not state their status.

\subsection{Descriptive analysis of the monitoring of current and future needs of the travellers in the "Sedmica plus" travel agency from Negotin}

In the aim of "counting" the frequency of responses of current and future needs of the clients in the "Sedmica plus" Travel Agency from Negotin, we used the descriptive analysis.

1. On your journeys, you most commonly go with:

\begin{tabular}{|c|l|r|r|r|r|}
\hline \multicolumn{2}{|c|}{} & Frequency & \multicolumn{1}{|c|}{ Percent } & \multicolumn{1}{c|}{$\begin{array}{c}\text { Valid } \\
\text { Percent }\end{array}$} & $\begin{array}{c}\text { Cumulative } \\
\text { Percent }\end{array}$ \\
\hline \multirow{4}{*}{ Valid } & Friends & 22 & 19,8 & 19,8 & 19,8 \\
\cline { 2 - 6 } & Girlfriend/boyfriend & 18 & 16,2 & 16,2 & 36,0 \\
\cline { 2 - 6 } & Family & 64 & 57,7 & 57,7 & 93,7 \\
\cline { 2 - 6 } & Alone & 7 & 6,3 & 6,3 & 100,0 \\
\cline { 2 - 6 } & Total & 111 & 100,0 & 100,0 & \\
\hline
\end{tabular}

Table 1 . On your journeys, you most commonly go with - descriptive analysis

The obtained results show that the highest percent of interviewees, $57.7 \%$, go on their journeys with their families. With friends $19.8 \%$, with a boyfriend/girlfriend $16.2 \%$, while the lowest percent of interviewees travel alone, $6.3 \%$ (Table 1 ). 
2. Through our agency, you most commonly travel to:

\begin{tabular}{|c|l|r|r|r|r|}
\hline \multicolumn{2}{|c|}{} & Frequency & \multicolumn{1}{c|}{ Percent } & \multicolumn{1}{c|}{$\begin{array}{c}\text { Valid } \\
\text { Percent }\end{array}$} & $\begin{array}{c}\text { Cumulative } \\
\text { Percent }\end{array}$ \\
\hline \multirow{5}{*}{ Valid } & Summer vacation & 85 & 76,6 & 76,6 & 76,6 \\
\cline { 2 - 6 } & Winter vacation & 3 & 2,7 & 2,7 & 79,3 \\
\cline { 2 - 6 } & $\begin{array}{l}\text { Holiday/weekend vaca- } \\
\text { tions }\end{array}$ & 23 & 20,7 & 20,7 & 100,0 \\
\cline { 2 - 6 } & Total & 111 & 100,0 & 100,0 & \\
\hline
\end{tabular}

Table 2. The most common journeys through the agency - descriptive analysis

According to the obtained data, interviewees using the "Sedmica plus" services, most commonly travel to summer vacations, i.e. $76.6 \%$. Then there are $20.7 \%$ interviewees who travel for a holiday/weekend, while the lowest percent of interviewees go to winter vacations, $2.7 \%$ (Table 2).

3. The destination you most often opt for:

\begin{tabular}{|c|l|r|r|r|r|}
\hline \multicolumn{2}{|c|}{} & Frequency & \multicolumn{1}{c|}{ Percent } & \multicolumn{1}{c|}{$\begin{array}{c}\text { Valid } \\
\text { Percent }\end{array}$} & $\begin{array}{c}\text { Cumulative } \\
\text { Percent }\end{array}$ \\
\hline \multirow{6}{*}{ Valid } & Greece & 78 & 70,3 & 70,3 & 70,3 \\
\cline { 2 - 6 } & Turkey & 6 & 5,4 & 5,4 & 75,7 \\
\cline { 2 - 6 } & Spain & 7 & 6,3 & 6,3 & 82,0 \\
\cline { 2 - 6 } & Italy & 10 & 9,0 & 9,0 & 91,0 \\
\cline { 2 - 6 } & Egypt & 2 & 1,8 & 1,8 & 92,8 \\
\cline { 2 - 6 } & Other & 8 & 7,2 & 7,2 & 100,0 \\
\cline { 2 - 6 } & Total & 111 & 100,0 & 100,0 & \\
\hline
\end{tabular}

Table 3. The destination you most often opt for - descriptive analysis

According to the obtained results, the highest percent of interviewees most commonly opt for Greece as their destination, i.e. 70.3\%. Italy takes the second place with $9 \%$ of interviewees, then Spain with 6.3\%, Turkey 5.4\%, Egypt 1.8\% and 7.2\% of interviewees stated something else as their most common travel destination. That field was filled in with: European destinations, Serbia, Bulgaria, France (Table 3).

4. Would you like to see any other destination in our Agency's offer and which one?

\begin{tabular}{|c|l|r|r|r|r|}
\hline \multicolumn{2}{|c|}{} & Frequency & Percent & \multicolumn{1}{c|}{$\begin{array}{c}\text { Valid } \\
\text { Percent }\end{array}$} & $\begin{array}{c}\text { Cumulative } \\
\text { Percent }\end{array}$ \\
\hline \multirow{3}{*}{ Valid } & Yes & 58 & 52,3 & 52,3 & 52,3 \\
\cline { 2 - 6 } & No & 53 & 47,7 & 47,7 & 100,0 \\
\cline { 2 - 6 } & Total & 111 & 100,0 & 100,0 & \\
\hline
\end{tabular}

Table 4. Desire for some other destination - descriptive analysis

The research results show that more than half of the research sample (52.3\%) want to see some other destination in the Agency's offer, while 47.7\% think that the existing Agency's offer does not have to be expanded (Table 4). As suggestions, the interviewees named the following destinations (some respondents gave several suggestions): Serbia, France, Portugal, Rome, Athens, Paris, Berlin, Montenegro, Germany, Amsterdam, America, Croatia, Tunisia, Ibiza, Thailand, Bulgaria, the Maldives, Cyprus, Ireland, Russia, Malta, Cuba, Morocco, camping offers, Zanzibar, Austria, Barcelona, Lisbon, Qatar, Dubai, Romania, Italy, etc. 
5. Type of transport you use for your journeys:

\begin{tabular}{|c|l|r|r|r|r|}
\hline \multicolumn{2}{|c|}{} & Frequency & \multirow{2}{*}{ Percent } & \multicolumn{1}{c|}{$\begin{array}{c}\text { Valid } \\
\text { Percent }\end{array}$} & $\begin{array}{c}\text { Cumulative } \\
\text { Percent }\end{array}$ \\
\hline \multirow{4}{*}{ Valid } & Personal transport & 37 & 33,3 & 33,3 & 33,3 \\
\cline { 2 - 6 } & Bus & 55 & 49,5 & 49,5 & 82,9 \\
\cline { 2 - 6 } & Airline & 19 & 17,1 & 17,1 & 100,0 \\
\cline { 2 - 6 } & Total & 111 & 100,0 & 100,0 & \\
\hline
\end{tabular}

Table 5. Type of transport when travelling - descriptive analysis

The research results show that the highest percent of interviewees, $49.5 \%$, buy travel packages that include bus transport, $33.3 \%$ use their own transport, while the lowest percent, $17.1 \%$, travel by an airplane (Table 5).

6. On you travel package deals you most often spend:

\begin{tabular}{|c|l|r|r|r|r|}
\hline \multicolumn{2}{|c|}{} & Frequency & Percent & $\begin{array}{c}\text { Valid } \\
\text { Percent }\end{array}$ & $\begin{array}{c}\text { Cumulative } \\
\text { Percent }\end{array}$ \\
\hline \multirow{4}{*}{ Valid } & Up to 200€ & 19 & 17,1 & 17,1 & 17,1 \\
\cline { 2 - 6 } & Between 200€ and 300€ & 39 & 35,1 & 35,1 & 52,3 \\
\cline { 2 - 6 } & Between 300€ and 500€ & 40 & 36,0 & 36,0 & 88,3 \\
\cline { 2 - 6 } & More than 500€ & 13 & 11,7 & 11,7 & 100,0 \\
\cline { 2 - 6 } & Total & 111 & 100,0 & 100,0 & \\
\hline
\end{tabular}

Table 6 . The amount of money usually spent on package deals - descriptive analysis

According to the research results, the highest percent of respondents spend between 300 and $500 €$ on their package deals. A slightly lower percent, 35.1\%, buy package deals in the amount between 200 and $300 €$, while $17.1 \%$ buy package deals that cost no more than $200 €$. The lowest percent, $11.7 \%$, buy package deals in the amount of more than $500 €$ (Table 6).

7. For some future journeys, you would be prepared to spend how much more money:

\begin{tabular}{|c|l|r|r|r|r|}
\hline \multicolumn{2}{|c|}{} & Frequency & \multicolumn{1}{c|}{ Percent } & \multicolumn{1}{c|}{$\begin{array}{c}\text { Valid } \\
\text { Percent }\end{array}$} & $\begin{array}{c}\text { Cumulative } \\
\text { Percent }\end{array}$ \\
\hline \multirow{5}{*}{ Valid } & $\begin{array}{l}\text { I am not prepared to spend } \\
\text { more money }\end{array}$ & 17 & 15,3 & 15,3 & 15,3 \\
\cline { 2 - 6 } & Up to 100€ & 23 & 20,7 & 20,7 & 36,0 \\
\cline { 2 - 6 } & Between $100 €$ and 200€ & 46 & 41,4 & 41,4 & 77,5 \\
\cline { 2 - 6 } & More than 200€ & 25 & 22,5 & 22,5 & 100,0 \\
\cline { 2 - 6 } & Total & 111 & 100,0 & 100,0 & \\
\hline
\end{tabular}

Table 7. Additional money for package deals - descriptive analysis

According to the research results, the highest percent of respondents, $41.4 \%$, would be ready to spend the additional 100 to $200 €$ on their future deals, $22.5 \%$ would be ready to spend more than $200 €$, while $20.7 \%$ would be ready to spend up to $100 €$ more. The lowest percent, $15.3 \%$, would not be ready to spend extra money for their future package deals (Table 7).

8. In the Agency's offer, you would like to see more package deals that include the content for:

\begin{tabular}{|l|c|c|c|c|}
\hline & Frequency & Percent & $\begin{array}{c}\text { Valid } \\
\text { Percent }\end{array}$ & $\begin{array}{c}\text { Cumulative } \\
\text { Percent }\end{array}$ \\
\hline
\end{tabular}




\begin{tabular}{|c|c|c|c|c|c|}
\hline \multirow{4}{*}{ Valid } & Children & 22 & 19,8 & 19,8 & 19,8 \\
\cline { 2 - 5 } & $\begin{array}{c}\text { Relaxation, away from } \\
\text { crowd and night life }\end{array}$ & 60 & 54,1 & 54,1 & 73,9 \\
\cline { 2 - 6 } & Fun and entertainment & 29 & 26,1 & 26,1 & 100,0 \\
\cline { 2 - 6 } & Total & 111 & 100,0 & 100,0 & \\
\hline
\end{tabular}

Table 8. More package deals with the content for-descriptive analysis

According to the research results, more than half of the research sample, 54.1\% would like to see more package deals that offer relaxation, away from crowd and night life, $26.1 \%$ would like to see more deals that offer fun and entertainment, while the lowest percent, i.e. $19.8 \%$, would like to see more deals that offer content for children (Table 8).

9. How did you hear about our agency:

\begin{tabular}{|l|l|r|r|r|r|}
\hline \multicolumn{2}{|c|}{} & Frequency & \multicolumn{1}{c|}{ Percent } & \multicolumn{1}{c|}{$\begin{array}{c}\text { Valid } \\
\text { Percent }\end{array}$} & $\begin{array}{c}\text { Cumulative } \\
\text { Percent }\end{array}$ \\
\hline \multirow{5}{*}{ Valid } & Via social networks & 11 & 9,9 & 9,9 & 9,9 \\
\cline { 2 - 6 } & $\begin{array}{l}\text { Via advertisements on ra- } \\
\text { dio or TV stations }\end{array}$ & 1 &, 9 &, 9 & 10,8 \\
\cline { 2 - 6 } & Recommendation & 93 & 83,8 & 83,8 & 94,6 \\
\cline { 2 - 6 } & Other & 6 & 5,4 & 5,4 & 100,0 \\
\cline { 2 - 6 } & Total & 111 & 100,0 & 100,0 & \\
\hline
\end{tabular}

Table 9. How respondents found about the Agency - descriptive analysis

According to the research results, the highest percent, $83.8 \%$, had visited the Agency after having been given a recommendation, 9.9\% heard about it via social networks, in some other way $5.4 \%$, while the lowest percent of respondents, $0.9 \%$, heard about the Agency via radio or TV commercial (Table 9). As other ways of finding about the Agency, the respondents stated: knowing people who work there, the Agency is in their neighborhood, they know the Agency owner, they have seen the Agency.

10. Are you satisfied with your so-far travel experience with our Agency:

\begin{tabular}{|l|l|r|r|r|c|}
\hline \multicolumn{2}{|l|}{} & Frequency & Percent & $\begin{array}{c}\text { Valid } \\
\text { Percent }\end{array}$ & $\begin{array}{c}\text { Cumulative } \\
\text { Percent }\end{array}$ \\
\hline Valid & yes & 111 & 100,0 & 100,0 & 100,0 \\
\hline
\end{tabular}

Table 10. Satisfaction with the so-far experience with the Agency - descriptive analysis

All respondents stated they were satisfied with their so-far experience with the "Sedmica plus" Travel Agency (Table 10). 


\subsection{Main factors affecting the choice of a package deal}

In order to determine the main factors affecting the choice of package deals of the travellers in the "Sedmica plus" Travel Agency from Negotin, we applied the factor analysis. Only the key statement words shall be presented in the tables.

Factor analysis was carried out on 9 selected variables: journey type, destination, age, transport type, travel partners, one wishes more package deals, journey price (money most often spent), they would spend extra money on future deals, they wish for a different offer (more destinations).

Method application conditions, Table 11.

\begin{tabular}{|l|l|r|}
\hline \multicolumn{2}{|c|}{ KMO and Bartlett's Test } \\
\hline Kaiser-Meyer-Olkin Measure of Sampling Adequacy. &, 608 \\
\hline \multirow{3}{*}{ Bartlett's Test of Sphericity } & Approx. Chi-square & 189,458 \\
\cline { 2 - 3 } & Df & 36 \\
\cline { 2 - 3 } & Sig. &, 000 \\
\hline
\end{tabular}

Table 11. KMO and Bartlett's Test

As $\mathrm{KMO}>0.6$ and $\mathrm{Sig}<0.05$ it can be concluded that the factor analysis can be applied.

After examining the applicability of the method, we applied the Principal Component Analysis and by applying a criterion that the Initial Eigenvalue is higher than 1, we selected 3 factors that explain $59.794 \%$ of the total variance.

\begin{tabular}{|c|c|c|c|c|c|c|c|c|c|}
\hline \multirow{2}{*}{$\begin{array}{c}\text { Compo- } \\
\text { nent }\end{array}$} & \multicolumn{3}{|c|}{ Initial Eigenvalues } & \multicolumn{3}{|c|}{\begin{tabular}{|c|}
$\begin{array}{c}\text { Extraction Sums of Squared } \\
\text { Loadings }\end{array}$ \\
\end{tabular}} & \multicolumn{3}{|c|}{$\begin{array}{c}\text { Rotation Sums of Squared } \\
\text { Loadings }\end{array}$} \\
\hline & Total & $\begin{array}{c}\% \text { of } \\
\text { Variance }\end{array}$ & $\begin{array}{l}\text { Cumula- } \\
\text { tive } \%\end{array}$ & Total & $\begin{array}{c}\% \text { of } \\
\text { Variance }\end{array}$ & $\begin{array}{c}\text { Cumula- } \\
\text { tive \% }\end{array}$ & Total & $\begin{array}{c}\% \text { of } \\
\text { Variance }\end{array}$ & $\begin{array}{l}\text { Cumula- } \\
\text { tive \% }\end{array}$ \\
\hline 1 & 2,375 & 26,39 & 26,39 & 2,375 & 26,39 & 26,39 & 1,965 & 21,834 & 21,834 \\
\hline 2 & 1,7 & 18,891 & 45,282 & 1,7 & 18,891 & 45,282 & 1,756 & 19,515 & 41,349 \\
\hline 3 & 1,306 & 14,512 & 59,794 & 1,306 & 14,512 & 59,794 & 1,66 & 18,445 & 59,794 \\
\hline 4 & 0,889 & 9,875 & 69,668 & & & & & & \\
\hline 5 & 0,804 & 8,935 & 78,603 & & & & & & \\
\hline 6 & 0,717 & 7,969 & 86,572 & & & & & & \\
\hline 7 & 0,486 & 5,396 & 91,968 & & & & & & \\
\hline 8 & 0,414 & 4,6 & 96,568 & & & & & & \\
\hline 9 & 0,309 & 3,432 & 100 & & & & & & \\
\hline
\end{tabular}

Table 12. Factor analysis - total variance explained

By applying Varimax Rotation with Kaiser Normalization, Table 13, factor weights for certain factors can be easily noticed. 


\begin{tabular}{|l|r|r|r|}
\hline \multicolumn{4}{|c|}{ Rotated Component Matrix ${ }^{a}$} \\
\hline & \multicolumn{3}{|c|}{ Component $^{-1}$} \\
\cline { 2 - 4 } & $\mathbf{1}$ & $\mathbf{2}$ & $\mathbf{3}$ \\
\hline Most commonly travel &, 819 &,- 266 &,- 037 \\
\hline Choosing destinations &, 773 &,- 193 &, 177 \\
\hline Age &, 663 &, 379 &,- 135 \\
\hline Transport &, 350 &,- 347 &, 325 \\
\hline Most commonly go with &, 035 &, 811 &,- 004 \\
\hline More package deals &, 274 &,- 764 &,- 154 \\
\hline Most commonly spend &,- 136 &, 313 &, 781 \\
\hline Extra money &,- 026 &, 048 &, 768 \\
\hline More destinations &,- 201 &, 208 &,- 528 \\
\hline Extraction Method: Principal Component Analysis. & & \\
Rotation Method: Varimax with Kaiser Normalization. \\
\hline a. Rotation converged in 6 iterations.
\end{tabular}

Table 13. Varimax with Kaiser Normalization

Only factor weights greater than 0.3 were observed and 3 factors were identified.

The first factor refers to the journey type (summer, winter, and holiday/weekend), destination, age and type of transport. The highest factor weights are journey type and destination. We can describe it as the Journey type, destination and age.

The second factor refers to whom the travellers want to travel with (friends, boyfriend/girlfriend, family, alone), a variable of several package deals that include content for children, relaxation, away from crowds and night life, fun/entertainment. We can describe it as Journey partners.

The third factor refers to finances (variables Most often spend, Extra money, More destinations). We can describe it as the Financial factor. (Picture 1).

- Type of journey, destination and travellers' age

- Journey partners,

- Financial factor.

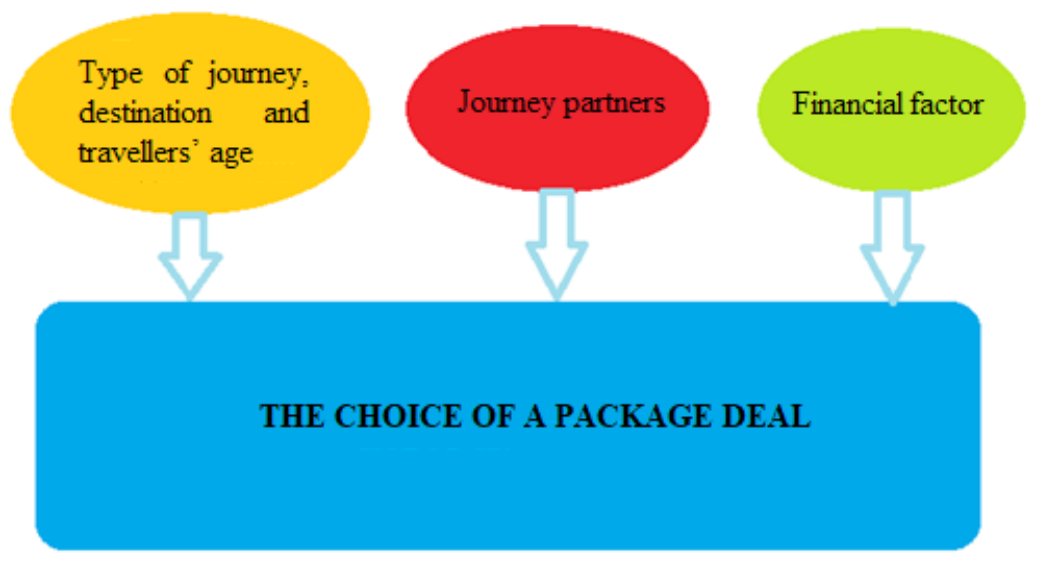

Picture 1. Factors affecting the choice of a package deal

Source: authors 


\subsection{Predictive modelling for determining if the travellers are satisfied with the agency's offer or if they want its expansion}

What needed to be predicted was the travellers' response to the Agency's offer, i.e. the question: are you satisfied with the existing offer: Yes-No and for the purpose of the model this variable was called "JOSH".

Predictive modelling of the SPSS program was applied: Binary Logistic Regression.

The observed factors (predictors) are: travellers' status, most often spend, journey partners and age.

Table 14 presents the model without the influence of predictors.

Block 0

\begin{tabular}{|c|c|c|c|c|c|}
\hline \multicolumn{6}{|c|}{${\text { Classification Table }{ }^{a, b}}$} \\
\hline & Observed & & \multicolumn{3}{|c|}{ Predicted } \\
\hline & & \multicolumn{2}{|c|}{ JOSH } & Percentage & \\
\hline & & $\mathbf{0}$ & 1 & Correct & \\
\hline \multirow{3}{*}{ Step 0} & \multirow{2}{*}{ JOSH } & 0 & 59 & 0 & 100,0 \\
\hline & & 1 & 52 & 0 & ,0 \\
\hline & \multicolumn{2}{|c|}{ Overall Percentage } & & & 53,2 \\
\hline
\end{tabular}

Table 14. Classification Table

The model correctly classifies $53.2 \%$ of all cases.

By inserting predictors, the following model is observed:

Block 1

\begin{tabular}{|l|l|r|r|r|}
\hline \multicolumn{9}{|c|}{ Omnibus Tests of Model Coefficients } \\
\hline \multirow{3}{*}{ Step 1 } & Chi-square & \multicolumn{1}{c|}{ df } & \multicolumn{2}{c|}{ Sig. } \\
\hline & Step & 17,332 & 4 &, 002 \\
\cline { 2 - 5 } & Block & 17,332 & 4 &, 002 \\
\cline { 2 - 5 } & Model & 17,332 & 4 &, 002 \\
\hline
\end{tabular}

Table 15. Omnibus Tests of Model Coefficients

As Sig $=0.002<0.05$ the model presents better results.

\begin{tabular}{|l|r|r|r|}
\hline \multicolumn{4}{|c|}{ Model Summary } \\
\hline Step & $\mathbf{- 2 ~ L o g ~ l i k e l i h o o d ~}$ & Cox \& Snell R Square & Nagelkerke R Square \\
\hline 1 & $136,105^{\mathrm{a}}$ &, 145 &, 193 \\
\hline \multicolumn{4}{|c|}{ Estimation terminated at iteration number 4 because parameter estimates changed by less than, 001.} \\
\hline
\end{tabular}

Table 16. Model Resume

The model explains between 14.5 and $19.3 \%$ of the variance.

\begin{tabular}{|l|r|r|rr|}
\hline \multicolumn{5}{|c|}{ Hosmer and Lemeshow Test } \\
\hline Step & Chi-square & df & \multicolumn{2}{c|}{ Sig. } \\
\hline 1 & 6,562 & & 7 & \\
\hline
\end{tabular}

Table 17. Hosmer and Lemeshow Test 
The results of the Hosmer and Lemeshow Test, Table 17, show that the model is correct since Sig $=0.476>0.05$.

\begin{tabular}{|c|c|c|c|c|c|}
\hline \multicolumn{6}{|c|}{ Classification Table $^{a}$} \\
\hline & Observed & & \multicolumn{3}{|l|}{ Predicted } \\
\hline & & \multicolumn{2}{|c|}{ JOSH } & Percentage & \\
\hline & & 0 & 1 & Correct & \\
\hline \multirow{3}{*}{ Step 1} & \multirow{2}{*}{ JOSH } & 0 & 46 & 13 & 78,0 \\
\hline & & 1 & 24 & 28 & 53,8 \\
\hline & \multicolumn{2}{|c|}{ Overall Percentage } & & & 66,7 \\
\hline
\end{tabular}

Table 18. Classification Table

The model correctly classifies $66.7 \%$ of all cases, Table 18 .

\begin{tabular}{|c|c|c|c|c|c|c|c|c|c|}
\hline \multicolumn{10}{|c|}{ Variables in the Equation } \\
\hline & & \multirow{2}{*}{$\boldsymbol{B}$} & \multirow{2}{*}{ S.E. } & \multirow{2}{*}{ Wald } & \multirow{2}{*}{$d f$} & \multirow{2}{*}{ Sig. } & \multirow{2}{*}{$\begin{array}{c}\text { Ex- } \\
p(B) \\
\text { Lower } \\
\end{array}$} & \multicolumn{2}{|c|}{$\begin{array}{c}\text { 95\% C.I. for } \\
\text { EXP(B) }\end{array}$} \\
\hline & & & & & & & & Upper & \\
\hline \multirow{5}{*}{ Step $1^{\text {a }}$} & Status &,- 317 & ,206 & 2,358 & 1 &, 125 & ,728 & ,486 & 1,091 \\
\hline & $\begin{array}{l}\text { Most often } \\
\text { spend }\end{array}$ &,- 731 & ,255 & 8,204 & 1 &, 004 & ,482 & ,292 & ,794 \\
\hline & $\begin{array}{l}\text { Journey } \\
\text { partners }\end{array}$ &,- 816 & ,300 & 7,383 & 1 & ,007 & ,442 & ,246 & ,797 \\
\hline & Age & ,117 & ,193 & ,368 & 1 & ,544 & 1,124 &, 770 & 1,640 \\
\hline & Constant & 3,475 & 1,144 & 9,236 & 1 &, 002 & 32,308 & & \\
\hline
\end{tabular}

Table 19. Variables

As Sig<0.05, variables "most often spend" and "journey partners", i.e. for the financial moment that is here presented through the package deal price and journey type, have an impact on the model.

Predictive model for asking for another destination can be presented as:

$\mathrm{Y}=-0.731 *$ most often spend $-0.816 *$ journey partners +3.475

We want to predict the probability of the answer that a person has a problem with the destinations in the Agency's offer, i.e. that they want another destination.

As the result is $(\operatorname{Exp}(B)=0,482)<1$, which means that for the increase in the amount of money travellers are willing to spend, the probability that the traveller wants another destination is 0.482 time lower with all other model parameters unchanged. That means that the Agency has a certain price and offer level because the probability that travellers want other destinations, with an increase in their readiness to pay for a more expensive package deal, is lower. 


\section{CONCLUSION}

All new tendencies in tourism that reflect in the occurrence of a sophisticated tourist demand, political changes, development of new technology, market segmentation, globalization, economic integration and many other important happenings, have contributed to the complexity of management in tourism. Hence, today and in the future, the tasks of strategic management imply a significantly broader field on which to find and create new markets. In order to ensure a permanent resource inflow and a continual service output, managers in tourism need to adjust to all new changes. Processes and complexities on the tourist market require modern managers working in tourism to invest a continual and constant effort in finding new strategies, innovating and creating new tourist products, adjusting their strategies to new tendencies and all in the aim of completely responding to new customer demands, maintaining and promoting their market position and successfully reacting to competitive challenges and pressures. Likewise, competition on the tourist market, as well as in the majority of other industries, is becoming increasingly harsh, hence the work of a manager in this sector can today be described as extremely challenging and dynamic.

In accordance with the results obtained in the empirical section, as far as the first hypothesis is concerned, i.e. "Travellers of the "Sedmica plus" Travel Agency are satisfied with the existing offer and do not want its expansion", it has been partially confirmed because the research has showed that travellers are really satisfied with the existing offer and their experience with the "Sedmica plus" Travel Agency, but they would also like to see more destinations in the Agency's offer.

The second hypothesis "Finances are an important factor when deciding where to travel" has been confirmed because the results obtained via factor analysis have shown that finances affect how travellers decide on their package deals. Likewise, the results show that the Agency has a certain level of offer and prices to which travellers are accustomed and that it is highly unlikely that travellers want other destinations by at the same time being willing to pay for a more expensive package deal.

The aim of this paper was to, through an empirical research, identify what travellers of the "Sedmica plus" Travel Agency from Negotin prefer when travelling and what they want in the future. Based on that, recommendations that could help managers in making important strategic decisions and make their business more successful have been drawn:

- Focus on journeys with family package deals;

- Holiday/weekend journeys, that reached second place as according to travellers' interests, could be enhanced by offering trips to European metropolises and across Serbia for which the interviewed travellers have showed interest. This could possibly strengthen this segment;

- Nurture the existing Greece offers and maybe enrich it with new content, since it was the number 1 destination for our respondents;

- Introduce an offer for long-distance trips, as a type of individual or group package deals. Think about hiring somebody new who will work solely on individual journeys to long-distance destinations;

- Package deals most acceptable amongst the travellers are the one within the price range of no more than $500 €$ and the Agency should try hard to give them the best quality service for that price in order to keep the good reputation;

- Prices of future package deals should not be higher than $200 €$ in comparison to the existing ones. 
- Offer more package deals offering relaxation, away from crowds and night life.

- Assessment of customer needs should exist as a permanent activity; the offer should be of good quality and employees need to be professional and kind in order to keep the positive image the Agency has (because all respondents stated they were satisfied with the so-far experience with the Agency) and in order for the word-of-mouth marketing to keep functioning well;

- The highest percent of respondents have heard about the Agency via recommendation which is the best possible way of advertising and it is a positive thing, but the management could also think about increasing the intensity of radio and TV commercials as well as their presence on social networks in order to make the Agency more out there;

- Low percent of travellers using the winter vacations can be interpreted as a result of a low standard of living, hence it is necessary to inform potential travellers about the possibility of a more affordable prices of skiing equipment, accommodation and about the great health benefits of spending time on the mountain;

- Given the fact that more than a half of the research sample stated they prefer to use the bus transport, the management should think about expanding their transport resources, i.e. buying at least one more bus.

\section{REFERENCES}

[1] Robbins,P. S., Judge,A. T. (2009) Organizational behaviour, 12 ${ }^{\text {th }}$ edition, Mate, Zagreb, pp.23.

[2] Arnold, F. (2015) Menadžment - učite od najboljih, Laguna, Beograd, pp. 42.

[3] Pavlović, D., Spasić, V. (2008) Efekti primene savremene informacione tehnologije u poslovanju malih turističkih agencija, Turizam i hotelijerstvo, pp. 151-152.

[4] https://www.slideshare.net/sjovanovic/uvodjenje-crma, access 10.10.2018.

[5] Stefanović, V. (2017) Tourist needs as determinants of tourism development, Ekonomski signali, 12(1): 013-029, pp. 16

[6] Ilić B., Stefanović, V. (2018), Planning as an element of strategic management in tourism, Trendovi u poslovanju, vol. 6, no. 2, pp.12.

[7] Stefanović, V. (2017) Tourist needs as determinants of tourism development, Ekonomski signali, 12(1): 013-029, pp. 17.

[8] Bošković, T., Mihajlović, M. (2016) Contemporary trends in international tourism market, Škola biznisa, 1/2016, pp. 124

[9] Petrović, P., Dželetović, M. (2016) Impact of entrepreneurial education on consumer loyalty in tourism industry, Turističko poslovanje, Broj 18, pp. 18

[10] Petrović G., Karabašević, D., Maksimović, M. (2016) Promet turista i prihodi od turizma u republici Srbiji, Ekonomski signali, 11(2), pp. 62.

[11] Mašić B., Muhi, B., Nešić S., Jovanović, D. (2017) Strategijsko upravljanje u turizmu: kako kreirati konkurentsku prednost kod turističkih destinacija, Poslovna ekonomija, vol. 11, no. 1, pp. 195-196, 2017, doi:10.5937/poseko11-12360

[12] Cameron, S. K., Quinn, E. R. (2006). Diagnosing and changing organizational culture; Based on competing values framework, revised edition. San Francisco, The Jossey-Bass A Wiley Imprint, pp.7

[13] Hamel, G., Brin, B. (2009) The future of management, Asee, Novi Sad, pp.22

[14] Gavrić G., Kirin S., Čukanović Karavidić M. (2016), Adaptability of companies in the republic of Serbia - empirical research, Ekonomika, number 4, pp. 120 
[15] Kirin S., Gavrić G. (2017) Improvement of organizational culture as a managing tool for achieving business success in tourism-case study for Serbia, The second international thematic monograph: „Modern management tools and economy of tourism sector in present era", Association of Economists and Managers of the Balkans, Belgrade, Faculty of Tourism and Hospitality, Ohrid, pp. 316

[16] edukacija.rs/poslovne-vestine/marketing/analiza-konkurencije, accessed 7.09.2018.

[17] Gavrić G., Kirin, S., Čukanović Karavidić, M. (2016) Adaptability of companies in the Republic of Serbia - empirical research, Ekonomika, number 4, doi:10.5937/ekonomika1604115G, pp. 118

[18] Karadeniz, M. (2009) Product positioning strategy in marketing management, Journal of Naval Science and Engineering, 5 (2), pp.104 